\title{
SVENSKA KRIMINALISTFÖRENINGEN 1911-1986 I ETT NORDISKT PERSPEKTIV
}

Utblickar och insyn

Av Alvar Nelson

\section{Inledning}

Inom Centralförbundet för socialt arbete (grundat 1903) verkade en Kriminalkommitté under ledning av straffrättsprofessorn (1906-40) vid Stockholms högskola Nils Stjernberg (1873-1943). På hans och förbundets initiativ inbjöds till en kriminalkongress 28-30 augusti 1911 i Stockholm. Den närmaste bakgrunden var Kungl Maj:ts uppdrag 1909 åt den ryktbare straffrättsprofessorn (1894-1926) vid Lunds universitet C. J. W. Thyrén (1861-1933) att förbereda ny strafflagstiftning. Redan 1910 framlade Thyrén första delen av Principerna för en strafflagsreform. Där behandlade han straffets uppgift och straffsystemets systematiska uppbyggnad. Enligt inbjudningen till kongressen var en strafflagsreform en fråga, som vore av den betydelse $i$ en nations liv och ägde så nära samband med dess allmänna samhälleliga åskådningar och tänkesätt, att redan föreberedelserna borde påkalla livligt, allmänt intresse. Initiativet stöddes av en stor krets av domare, ämbetsmän, advokater och läkare samt personer inom fångvården och socialvården.

Under kongressen bildades den 29 augusti 19.11 Svenska kriminalistföreningen med det mångfrestande justitierådet Hjalmar Westring (1857-1926) som sammankallande och senare ordförande (1912-1925) och med Stjernberg som primus motor (ordförande 1925-1938) och nästan 250 medlemmar. Efter Stjernberg följde som ordförande hovrättspresidenten Karl Schlyter (1879-1959) och han efterträddes 1950 av överdirektören för fångvårdsstyrelsen Hardy Göransson (1894-1969). Därefter kom 1959 justitierådet Nils Beckman (1902-1972), som tio år senare efterföljdes av justitierådet Carl Holmberg (f 1919). Sedan 1980 är riksåklagaren Magnus Sjöberg (f 1927) dess ordförande. Anslutningen av medlemmar har växlat. Kulmen nåddes på 1960-talet med inemot 800 och har därefter dalat och är numera under 500. Medlemstalet återspeglar i viss mån det allmänna intresset för kriminalpolitiska frågor och viljan att behålla publikationen.

I syskonskaran av nordiska kriminalistföreningar är Den norske kriminalistforening (grundad 1892) och Dansk kriminalistforening (bildad 1899) äldre och Kriminalistföreningen i Finland (grundad 1934) och Islands kriminalistförening 
(bildad 1949) yngre. När nu den svenska föreningen kan fira 75-årsjubileum är det tillfälle att från olika utgångspunkter bedöma dess verksamhet och framtidsutsikter. Även om fokus riktas mot jubilaren, fördjupas bilden av perspektivet.

\section{Impulserna från utlandet}

Det kan icke råda tvekan om, att 1800-talet var strafflagstiftningens stora århundrade. Då skapades den moderna straffrättsdogmatiken, då utformades de ledande straffteorierna och då omsattes principerna från läroböckerna i kommissionsbetänkanden till lagtext med motiv. Under samma tid förändrades synen på lagöverträdarna och deras förutsättningar att anpassas till samhället. Förbrytarna, som tillsammans med förlupna soldater, lösdrivare och försvarslösa hade satts till arbete i kronans fästningar, varv och smedjor, när de icke hängdes eller halshöggs, blev nu innespärrade $\mathrm{i}$ fängelser. Det militära kommandot över deras dagliga elände ändrades så småningom till moraliska påtryckningar. Umbärandena vid slavarbetet utomhus mildrades något, när enkla hantverk utfördes i celler eller arbetssalar. Hugg och slag dämpades, när kraven restes på underkastelse under religionens och samhällets föreskrifter.

I de nordiska länderna skapades nya strafflagar: i Danmark 1866 (och liknande i Island 1869), i Storfurstendömet Finland 1889, i Norge redan 1842 och i Sverige 1864. Under denna lagstiftningsperiod hade fångvården byggs ut med nya anstalter för att möta tillströmningen av straffångar och bötesfångar. Medan föreskrifterna rörande brotten länge blev en angelägenhet för juristerna, tilldrog sig ändringarna i straffsystemet mera allmänt intresse. Samhället tog in loco parentis ansvar för försummade och vanartiga barn för att med tukt och förmaningar forma dem till ödmjuka undersåtar. Sjukdomar till kropp och själ uppfattades icke längre som oundvikliga följder av ohörsamhet mot den högsta utan som plågor, vilka kunde lindras och rent av botas med mänsklig vård och behandling. Endast de lättjefulla och förhärdade ställdes ännu utanför samhället och blev föremål för moralisk förföljelse och skoningslöst tvång.

Även om man i de nordiska länderna länge hade haft kännedom om många utländska projekt till förbättringar inom straffsystemet, särskilt i fråga om frihetsstraffen, och även om patronageföreningar hade bildats $i$ anknytning till många fängelser, innebar de allt starkare banden till organisationer i utlandet med ideella syften ett betydelsesfullt steg i utvecklingen. Starkast kom detta till uttryck vid den andra internationella penitentiärkongressen, som hölls $1878 \mathrm{i}$ Stockholm. Då bildades också den nordiska penitentiärföreningen, som torde ha upphört med 1882 års möte i Oslo. Tack vara uppoffrande insatser av Frederik Stuckenberg (1832-1898) fick den genast ett språkrör i Nordisk Tidsskrift for Fængselsvæsen og øvrige penitentiære Institutioner, den första föregångaren 
till Nordisk Tidsskrift for Kriminalvidenskab (NTfK). Föreningens förste ordförande blev Köpenhamnsprofessorn Carl Goos (1835-1917), åren 1884-1901 tillika chef för den danska fångvården. Svensk ledamot av redaktionen var från början Thyréns företrädare professor Per Assarsson (1838-1894).

Mycket av intresset för »fångvårdsvetenskapen« flyttades så småningom över till kriminalistföreningarna, men annat togs till vara på olika sätt. Det praktiska, ideella arbetet utfördes i Sverige sedan 1879 av Centralförbundet för frigivna fångar, som tillsammans med andra organisationer 1925 bildade Svenska Skyddsförbundet, som ännu är livaktigt. Medan de lägre fångvårdstjänstemännen (fram till 1911 med militära benämningar) för fackliga ändamål 1906 grundade Sveriges fångvårdsmannaförbund med tidskriften Vård och vakt (1907-1954), samlades de högre med andra intresserade 1907 i Svenska fängvårdssällskapet, som ännu existerar. Den sedan 1945 utgivna Tidskrift för kriminalvård har nu upptagit några av de mera övergripande frågor, som sedan seklets början har intresserat de nämnda organisationernas medlemmar. Inom det nordiska samarbetet skall här också erinras om den första nordiska fängelsekongressen 1922 i Stockholm.

Även om alla de nordiska länderna under 1800-talet hade fått nya strafflagar, upplevde många, att lagarna redan vid sin tillkomst eller kort därefter icke motsvarade samtidens åskådningar och förväntningar för framtiden. Av stor betydelse blev det vittgående reformprogram, som hade framlagts av straffrättsprofessorn i Marburg Franz von Liszt (1851-1919) och 1889 lett till bildandet av Union internationale de droit pénal, 1924 ombildad till Association internationale de droit pénal (AIDP), medan tyskarna behöll unionen under dess tyska namn Internationale kriminalistische Vereinigung (IKV). Sammanslutningens tredje kongress ägde rum 1891 i Oslo. Den ledde omedelbart till bildándet 1892 av Den norske kriminalistforening på initiativ av professor Francis Hagerup (1853-1921) och en krets medlemmar av den internationella föreningen. När Dansk kriminalistforening stiftades 1899 på initiativ av Aug. Goll (1866-1936), senare riksåklagare och St. Grundtvig (1860-1942), fångvårdsman med professor Carl Torp (1855-1929) som ordförande, var hälften av dess medlemmar tillika medlemmar av den internationella. Den internationella föreningen hade bland dem som 1911 stiftade Svenska kriminalistföreningen över 50 medlemmar. Sedan 1973 finns i Sverige en lokalavdelning av AIDP med omkring 80 medlemmar, och Sjöberg som ordförande.

Det från början nära sambandet mellan den internationella kriminalistföreningen och de norska, danska och svenska kriminalistföreningarna visar stark intressegemenskap, men man värjde sig i Norden mot att binda sig för det idéprogram, som låg till grund för dess tillkomst. Numera är AIDPs program så vagt utformat, att ingen kan motsätta sig det. Det samma gäller i allt högre grad 
den från början kritiska 1949 stiftade Société internationale de Défense sociale, som numera har liten anslutning i Norden. På kriminalvårdens område fick den internationella utvecklingen an annan riktning. Redan på 1878 års kongress $\mathrm{i}$ Stockholm organiserades den mera formellt uppbyggda Comission internationale pénale et pénitentiaire (CIPP) med făngvårdsstyrelsens chef $G . F$. Almquist (1814-1886) som interimsordförande. CIPP, där Sverige icke var representerat under perioden 1900-1902, anordnade inalles 10 kongresser efter den i Stockholm. Dess funktioner övertogs 1951 av Förenta nationerna, och CIPP upplöstes men dess kapital lades till grund för den ännu verksamma Fondation internationale pénale et pénitentiaire (FIPP). Därefter har FN sedan 1955 anordnat internationella kongresser vart femte år, 1965 i Stockholm. Numera deltager huvudsakligen representanter för staternas regeringar och vissa internationella organsiationer. Därutöver finnes verksamhet inom vissa regionala organ med officiell status. Av störst betydelse för de nordiska länderna är den intensiva kontakt som sedan 1958 förekommer inom ramen för Europarådet genom dess Comité Européen pour les Problems Criminels (CEPC), vars arbete omfattar stora delar av kriminalvetenskapen ock kommitténs vetenskapliga råd med inriktning på kriminologisk forskning.

\section{Den nordiska bakgrunden}

De norska, danska och svenska kriminalistföreningarnas tillkomst står i nära samband med genomgripande reformer inom strafflagstiftningen. Tydligt framträder detta redan därigenom, att de första sammankomsterna med de norska och danska föreningarna öppnades av ländernas dåvarande justitieministrar, i Norge av O. A. Qvam (1834-1904) och i Danmark av Goos. Man kan emellertid icke därav draga slutsatserna, att föreningarna avsågs gå $\mathrm{i}$ regeringarnas ledband. Mellan Goos och den danska föreningens förste ordförande Torp fanns väl det gemensamma intresset av att skapa en ny strafflagstiftning, men om dess uppbyggnad och inriktning hade de skilda uppfattningar. Goos tillhörde, som redan nämnts, kretsen kring fångvårdsreformer i den internationella kommissionens anda och var icke medlem av den internationella unionens förening. I Sverige ställde sig Thyrén utanför kretsen inom den svenska föreningen, ehuru han ofta medverkade i sammankomsterna.

De nordiska kriminalistföreningarna har från första början varit fora för kriminalpolitiska debatter, ofta i nära anknytning till pågående lagreformer och återkommande med ämnen rörande unga eller psykiskt avvikande lagöverträdare, missbrukare och lösdrivare. Hur nära man följde med $\mathrm{i}$ den internationella debatten och $\mathrm{i}$ inhemska förslag till ny lagstiftning visas $\mathrm{i}$ synnerhet under den norska föreningens första år. Även om förberedelserna för den stora strafflagsreformen, under ledning av riksåklagaren Bernhard Getz 
(1850-1901), ofta ingick i överläggningarna, hade man livliga debatter rörande andra ämnen, som snabbare ledde till lagstiftning, nämligen 1894 års lag om villkorlig dom, 1896 års lag om försummade barn och 1900 års lag mot lösdriveri, bettleri och dryckenskap. Efter tillkomsten av 1902 års norska strafflag, avtog verksamheten men återupptogs ett årtionde senare och kom länge att präglas av Hartvig Nissen (1874-1945), 1924-1944 chef för Botsfængslet i Oslo.

På liknande sätt kom den danska kriminalistföreningen länge att präglas av kriminalpolitiska ämnen, men betoningen på utformningen av de straffrättsliga och socialrättsliga sanktionssystemen var starkare innan kommissionsförslagen avseende strafflagsreformen började framläggas. Inslaget av anföranden av läkare och fångvårdsmän var påfallande stort. Såväl den danska som redan tidigare den norska föreningen betonade sin anknytning till den internationella unionen och medlemskap där var tidvis en förutsättning för att vara ledamot av styrelsen. Motsvarande band lades också på den svenska föreningens styrelseledamöter.

Såsom redan inledningsvis nämndes motiverades tillkomsten av svenska kriminalistföreningen med det nyss påbörjade arbetet på en helt ny strafflagstiftning, Med Stjernberg som drivande kraft ägnade man särskilda ansträngningar åt samhällets reaktioner mot alkoholister, psykiskt avvikande lagöverträdare och återfallsbrottslingar. Alltsedan 1911 kom professor Olof Kinberg (1873-1960) att aktivt deltaga i diskussionerna i sådana ämnen. De socialetiska intressena var från början väl tillvaratagna av redaktören för Social Tidskrift (1901-1917) G. H. von Koch (1872-1948) och den kände fängelseprästen, slottspastorn Aug. Wirén (1868-1936), som var föreningens förste sekreterare.

Medan den norska föreningens verksamhet låg nere från 1913 till 1925 försökte de danska och svenska hålla intresset vid makt under första världskriget. Under 1920-talet dominerades den kriminalpolitiska debatten av frågor rörande brottspåföljder avsedda för psykiskt störda förbrytare och återfallsförbrytare, och detta kom även att gälla de tre kriminalistföreningarnas sammankomster.

Bildandet 1934 av kriminalistföreningen i Finland hade en mera dramatisk bakgrund i den antibrottslighetsvecka som under intryck av ökningen av Iösdriveriet och brottsligheten i Helsingfors organiserades och öppnades av justitieminister Allan Särkilahti (Serlachius) (1870-1935), som vid föreningens stiftande kort därefter blev dess första ordförande. De närmast följande åren hölls antibrottslighetsdagar i Viborg och Åbo förutom årssammanträdena med kriminalistföreningen. Då hade andra samhällsinsatser förtursrätt och en strafflagsreform hade långa utsikter. 


\section{Karl Schlyter och Svenska kriminalistföreningen}

Bland Svenska kriminalistföreningens många ryktbara medlemmar intager Schlyter en särställning. Redan när han vid dess bildande 1911 blev medlem, tillhörde han den internationella sammanslutningen. När Westring 1924 lämnade styrelsen, efterträddes han av Schlyter, och Schlyter valdes 1938 till ordförande efter Stjernberg. Intill sin död bevarade han ett levande intresse för föreningen, även om han efter tio år lämnade ordförandeposten till Göransson. För honom var föreningen ett språkrör och ett verktyg för den kriminalpolitik, som han representerade. Insatserna kom att sträcka sig över de andra nordiska föreningarna till de internationella organisationerna. I den allt mera vidgade ensemblen spelade han huvudrollen. Det patos han utstrålade hade sin källa i hans personliga övertygelse om möjligheterna att genom utökad social kontroll hjälpa människorna till ett bättre liv. För honom blev det starka samhället byggt på ansvarstagande - icke maktbegär.

Själv befryndad med Thyrén greps Schlyter redan som ung av visionen av en ny kriminalpolitik, men hans politiska åskådning förde honom längre än Thyrén kunde följa honom. Därtill kom, att han i motsats till Goos och Thyrén hade förvärvat en grundlig kunskap om rättegångsväsendet, fördjupad under tiden som sekreterare i processkommissionen (1919-1926). Han hade därför - i likhet med Getz - större förutsättningar att se det straffrättsliga reaktionssystemet som en helhet. Man kan alltifrån hans dissens 1908 i Amaltea-målet se hans vilja att beakta brottslingens sinnelag och bevekelsegrunder. Senare kom Schlyter att i sin syn på brottslingarnas sinnesbeskaffenhet nalkas Kinberg, och de samverkade ofta i föreningen, där denne var styrelseledamot sedan 1913, och i lagstiftningsarbetet.

Även om Schlyter som politiker hade en annan åskådning än flertalet av sina samtida inom föreningens styrelse, fann han i sina ansträngningar att skapa en ny strafflagstiftning i stor omfattning stöd inom föreningen.

När ett lagstiftningsärende första gången remitterades till föreningen, skedde det på initiativ av dåvarande justitieministern i Arvid Lindmans regering $G$. Bissmark (1871-1941). Ärendet gällde sterilisering. Vid årsmötet 1930 togs frågan upp med Kinberg som inledare. Han framhöll, att sådana ingrepp vore den allra viktigaste åtgärden mot försämring av folkstammen. Det var mot den bakgrunden, som Schlyter anslöt sig till ståndpunkten, att lagstiftning behövdes, där giltigt samtycke till åtgärden icke kunde erhållas. De skilda uppfattningarna som kom till uttryck under debatten föranledde föreningen att låta inläggen tala för sig själva. Knappt hade Schlyter hunnit tillträda 1932 som justitieminister, förrän han framlade sitt första program för en successiv reform av strafflagstiftningen och till sig knöt Thyréns efterträdare på professuren i Lund Ragnar Bergendal (1890-1980) till departementet och några månader senare gav denne i uppdrag att omarbeta förslaget efter Schlyters synpunkter. 
När Schlyter efter Thyréns död 1933 på våren 1934 hade låtit utarbeta en plan för det fortsatta reformarbetet remitterades en promemoria härom till föreningen, vars styrelse, utöver att uttala sin uppskattning, anlade särskilda synpunkter på vissa frågor. Därutöver anslöt sig styrelsen till grundtankarna i den av straffrättsprofessorn i Uppsala (1913-1948) Folke Wetter (1883-1961) författade särskilda promemorian rörande reformen av förmögenhetsbrotten. Wetter hade varit verksam i föreningen sedan dess tillkomst och sedan 1925 i dess styrelse. Flera av de punkter, som styrelsen i övrigt nämnt hade dryftats på tidigare sammanträden med föreningen.

Frågan om en ny slags påföljd och en ny anstalt för unga lagöverträdare hade länge varit aktuell, när Schlyter 1934 lät utreda saken. I utredningen, där Göransson spelade en aktiv roll, hade man tagit intryck av lösningen i Danmark. När betänkandet lämnades i slutet av året, lät Schlyter remittera det till föreningen, som genast tog upp ärendet på ett möte i februari 1935, varefter styrelsen avgav sitt yttrande. Under riksdagsbehandlingen gjorde första lagutskottet ett studiebesök i april 1935 i Danmark, där Goll höll ett orienterande föredrag om de danska erfarenheterna. Strax därefter antogs lagen.

Schlyter var ännu justitieminister 1936, då föreningen kunde se tillbaka på ett kvarts sekels kriminalpolitiska överläggningar och fram mot den första etappen av förnyelsen av den centrala strafflagstiftningen. Hela mötet ägnades åt det pågående reformarbetet. $\mathrm{Nu}$ gällde frågan ändringar i straffsatserna för särskilda brott på grundval av en inom justitiedepartementet utarbetad promemoria. Av särskilt intresse är den varning för tilltron till ett automatiskt samband mellan straffmaxima och allmänpreventiva effekter, som framfördes av Bergendal. När det gällde förmögenhetsbrotten anades bakom Wetters yttranden hänsyn till efterverkningarna av Kreugerkraschen. Störst uppmärksamhet tilldrog sig dock diskussionen om nedkriminalisering och avkriminalisering inom sedlighetsbrotten.

Mindre än ett halvt år senare fick Schlyter lämna taburetten, men hans efterföljare bondeförbundaren, rättshistorieprofessorn i Uppsala K. G. Westman (1876-1944) fullföljde lojalt men med vissa justeringar ( $\mathrm{t}$ ex $\mathrm{i}$ fråga om abortlagstiftningen) Schlyters reformprogram. Bland Westmans första åtgärder var att tillsätta Strafflagberedningen och förordna Schlyter till dess ordförande. Som politiker tillhörde Schlyter första kammaren och han valdes 1937 till första lagutskottets ordförande (1937-1947). Två år senare efterträdde han Stjernberg som ordförande $\mathrm{i}$ kriminalistföreningen och stannade på denna post $\mathrm{i}$ tio år. I dessa positioner hade han goda förutsättningar att föra sitt reformprogram framåt även under krigsårens samlingsregeringar.

Vid föreningens möten under 1939 ägnade man det första åt straffprocessuella frågor i anslutning till processlagberedningens förslag och det andra åt det 
allmängiltiga ämnet Allmänprevention och individualprevention med Nissen som inledare. Gentemot önskemålen att övergå till rent individualpreventiva, medicinska reaktioner mot en betydande del av lagöverträdarna, vände sig bl a Wetter och Ivar Agge (1903-1978) som 1941 efterträdde Stjernberg på straffrättsprofessuren. Medan Wetter menade, att allmänpreventionen skulle leda den allmänna rättsuppfattningen, nyanserade Agge ståndpunkten genom att tala om dess moralförstärkande eller moralvidmakthållande verkan. Båda stod de nära den opposition mot Thyrén som redan tidigt på 1920-talet framförts av Uppsalaskolan, först genom professorn i civilrätt Vilhelm Lundstedt (1882-1955), trots att denne gjort sina första lärospån hos Schlyter under dennes domaretid.

Bland föreningens möten under Schlyter skall bara några få nämnas. Brottmålsjuristens utbildning diskuterades 1943 med inledning av senare regeringsrådet Kurt Holmgren (f 1905) och med ett inlägg av den danska föreningens ordförande, professor Stephan Hurwitz (1900-1981). Hurwitz presenterade där en dotterförening, nämligen Dansk kriminologisk selskab, som ännu är aktiv, och rekommenderade en sådan lösning även i de övriga nordiska länderna. Vid årsmötet 1946 framträdde som förste talare den svensk-amerikanske kriminologen professor Thorsten Sellin (f 1896) som presenterade det amerikanska systemet med tidsobestämda frihetsberövanden som brottspåföljd. Vid den finska föreningens årsmöte 1947 talade Sellin åter kring samma ämne, och Schlyter meddelade då i ett skriftligt inlägg huvuddragen av strafflagberedningens kommande förslag till påföljdssystem och tog samtidigt avstånd från den alltför höga grad av obestämdhet $\mathrm{i}$ fråga om strafftid och behandling som förekom i U.S.A.

Vid det sista sammanträde med föreningen, där Schlyter presiderade, alltså 1949, diskuterade man med Agge som inledare övervägandena inom straffrättskommittén och strafflagsberedningen att införa ett enhetligt frihetsstraff. Medan den norska föreningens ordförande professor Johs. Andenas (f 1912) uttalade sig till förmån för ett frihetsstraff, hade Hurwitz vissa betänkligheter. Därvidlag fick han stöd av Wetter, som förordade möjligheten att använda ett privilegierat straff mot brottslingar av gruppövertygelse. Wetters efterträdare på professuren i Uppsala Ivar Strahl (f 1899) visade, att ett förenhetligande av frihetsstraffen kunde bli ett led i en utveckling, där bestämmandet av påföljdens verkliga beskaffenhet bleve förskjuten till en senare tidpunkt än domfällandet.

Detta sammanträde avslutades med att föreningen valde Schlyter till sin förste - och ännu så länge ende - hedersordförande.

\section{Karl Schlyter i det internationella samarbetet}

För Schlyter var Svenska kriminalistföreningen och dess syskonföreningar bara en av de stödjepunkter, som han begagnade för att föra sina kriminalpolitiska 
idéer ut i världen. Ändå kan man med visst fog göra gällande, att den var hans första och längst bestående plattform. Där stod han säkert före och efter sin framgångsrika bana som domare och ämbetsman, lagstiftare och politiker.

Det var 1934 som Schlyter inbjöd de nordiska ländernas justitieministrar till en konferens i Stockholm. Man överlade då om lämpliga sätt att anordna ett mera formlöst samarbete mellan de nordiska justitiedepartementen i lagstiftningsärenden. Samtidigt presenterades det svenska förslaget till abortlagstiftning och utkast till reformer i Sverige av bötesförvandlingsstraffet. Justitieministerkonferenserna har därefter fortsatt i olika former.

Den sjätte internationella kongressen, anordnad av den 1928 i Rom bildade Bureau international pour l'unification du droit pénal, hölls 1935 i Köpenhamn. Vid mötet överlade de nordiska ländernas delegater under ledning av Goll dels om ländernas anslutning till AIDP, dels om förutsättningarna för en sammansmältning av IKV med AIDP. Man ställde sig avvaktande och beslöt att icke fatta beslut utan samråd. Vid samma tillfälle föddes planerna på ett närmare samarbete mellan de nordiska kriminalistföreningarna dels inom Norden, dels i förhållande till världen i övrigt.

Vid den svenska föreningens möte 1936 tog Schlyter upp frågan om formerna för ett sådant samarbete, och förhandlingar upptogs mellan delegerade från de fyra föreningarna. Förhandlingarna gav omedelbart två resultat: besluten att utgiva en gemensam publikation och att hålla gemensamma möten. Den gemensamma skriften skulle innehålla referat av sammanträdena med de nationella föreningarna och en sammanfattning på främmande språk. Så tillkom De nordiska kriminalistföreningarnas årsbok, fr o m 1952 kallad Nordisk kriminalistisk årsbok (NKÅ). Den första volymen avseende 1936 utkom redan 1937 och innehöll även uppgifter rörande föreningarna samt några uppsatser. Länge var det Schlyter som bar ansvaret för utgivningen, som byggde på samarbete mellan föreningarnas sekretariat. Årsboken utkom sista gången 1968 med redovisning av 1963 års möten. Därmed var en epok avslutad.

Det andra, ännu bestående resultatet av 1936 års överläggningar var anordnandet av nordiska kriminalistmöten. Det första kom till stånd redan 1937 i Helsingfors och följdes av möten 1947 i Stockholm, 1952 i Köpenhamn, 1957 i Oslo, 1962 i Helsingfors, 1967 i Stockholm, 1973 i Köpenhamn, 1979 i Oslo och nu senast 1984 i Helsingfors, då den finska föreningen firade sitt 50-årsjubileum. Inledningsanförandena till överläggningsämnena och diskussionsinläggen har publicerats i NKA 1937, 1946, 1951-52, 1957 och 1962 samt därefter endast inledningarna i NTfK 1973, 1979-80 och 1984.

Redan vid 1937 års kriminalistmöte tog Schlyter upp frågan om möjligheterna att åstadkomma enhetlighet i de nordiska ländernas kriminalstatistik. På ett internationellt plan hade sådana planer om jämförbar statistik varit aktuell 
länge, och frågan drevs i Finland framför allt av den finska föreningens sekreterare professorn Veli Verkko (1893-1955). På nordiskt plan förekom överläggningar 1938 i Stockholm och 1939 i Oslo och de ledde 1941 till en av de delegerade för de nordiska kriminalistföreningarna publicerad utredning med förslag. Vid sammanträdet före 1947 års kriminalistmöte i Stockholm blev den återförvisad till de olika lokalstyrelserna. Först långt senare har Nordisk statistisk sekretariat tillgodosett önskemålen med sin rapport Nordisk kriminalstatistik 1950-1980.

Måhända uppfattade man icke kriminalstatistikens betydelse för den kriminologiska forskningen, som eljest omhuldades i de nordiska föreningarna och vars budskap man önskade föra fram i utbildningen och vidareutbildningen av juristerna. För Sveriges del var det ett statligt anslag som gjorde det möjligt att för ett år inbjuda Sellin till föreläsningar. Samtidigt fick det av Kinberg inrättade kriminologiska institutet en fast anknytning till Stockholms högskola (universitet). Opinionen på 1947 års kriminalistmöte i Stockholm gav ett starkt stöd åt kriminologisk forskning och utbildning och fördes därefter vidare genom föreningarnas styrelser. För Sverige innebar en utredning av Andenæs det avgörande steget framåt.

Den dåvarande svenske justitieministern Herman Zetterberg (1904-1957) inbjöd delegerade från de nordiska länderna till en kriminalrättskonferens i juni 1948 i Stockholm. Vid denna och senare konferenser i oktober 1948 i Oslo, mars 1949 i Köpenhamn, februari 1950 i Helsingfors, juni 1950 i Reykjavík, augusti 1951 i Stockholm, juni 1952 i Köpenhamn, februari 1954 i Oslo, oktober 1955 i Stockholm och oktober 1956 i Helsingfors dryftades kriminalpolitiska spörsmål. De hade vanligen nära anknytning till strafflagberedningens arbete, och Schlyter deltog i flertalet möten. Verksamheten synes icke ha fortsatt, sedan beredningens betänkande hade överlämnats.

Vid slutet av sin verksamhet som ordförande i den svenska föreningen tog Schlyter ett initiativ av vidare räckvidd. Här gällde det samarbete mellan de nordiska föreningarna och Förenta nationerna. Även här intog Sellin en nyckelställning som generalsekreterare i CIPP, där länderna var representerade. När Alva Myrdal (1902-1986) genom sin ställning i FNs Department of Social Affairs skulle organisera det internationella arbetet avseende kriminalpolitiken, erbjöds de nordiska föreningarna som enhet en särställning i verksamheten. Under 1949 tog Schlyter kontakt med de andra föreningarna och i fortsättningen härav bildades med stöd, särskilt från Hurwitz, De nordiska kriminalistföreningarnas internationella kommitté, där Sverige i början tog ledningen med Schlyter som ordförande och Strahl som sekreterare. 


\section{I väntan på Brottsbalken}

Under nära tjugo år, varav mer än ett decennium som ordförande, hade Schlyter och kretsen kring honom begagnat Svenska kriminalistföreningen som en plattform för den ideologi om ingripanden mot brott till skydd för samhället och för förövaren, som man hoppades kunna förverkliga i den kommande strafflagen - eller skyddslagen - som Schlyter ville benämna den. Budskapet har därifrån och från Schlyters politiska förankring i riksdagen och regeringen förts till de andra nordiska länderna och vidare ut $\mathrm{i}$ världen. Kriminalrättskonferenserna var ett medel att genom kontakt med ämbetsmän och politiska beslutsfattare $\mathrm{i}$ kretsen av styrelserna i de andra nordiska föreningarna fördjupa synen på brottsligheten och dess bekämpande. Som ett enat Norden skulle man kunna bidraga till kriminalpolitiska lösningar inom rammen för FNs verksamhet. Hemma i Sverige började straffrättskommittén med riksmarskalken Birger Ekeberg (1880-1968) som ordförande och strafflagberedningen under ledning av Schlyter avsluta sina uppdrag.

Det var i detta skede, som Göransson, liberal politiker och chef för fångvårdsstyrelsen under tio år skulle leda Svenska kriminalistföreningen. Det blev ett maktskifte just vid denna tidpunkt, då Gustav V gick i graven och hans son trädde till. Valet av ämne för 1950 års föreningsmöte var bestämt dessförinnan och gällde brott och publicitet med justitierådet Nils Beckman (1902-1972) som inledare. Han hade mött pressen redan som ung under rannsakningen av Sala-ligan. Ämnet fick en god belysning genom de upplysningar från Danmark, som Hurwitz meddelade, och talrika inlägg från pressens män. Det skulle bara dröja till 1952, innan Publicistklubben efter samråd bl a med en delegation utsedd av föreningens styrelse, antog nya publiceringsregler.

Strahl framträdde med inledningsanföranden dels 1952 om uppdelningen av straffprocessen på två avgöranden: skuld och påföljd, dels 1955 om rörelsen för socialskydd (défense sociale) - den senaste idériktningen inom straffrätten. Själv stod han som en av upphovsmännen för rörelsens minimiprogram från 1949 och i 1955 års möte deltog även rörelsens ledare den store franske juristen Marc Ancel (f 1902). I det första anförandet framhöll han behovet att noggrant pröva, hur den skyldige mest ändamålsenligt borde behandlas och i det senare, behovet att taga hänsyn till den dömdes utveckling under verkställighetens gång. Idag ter sig en så individualiserad påföljdsbestämning å ena sidan svår att genomföra och å andra sidan lätt att leda till orättvisa. Ändå är synpunkterna även nu värda eftertanke.

Tiden efter andra världskrigets slut kännetecknades av internationella och nationella strävanden att trygga de mänskliga och medborgerliga rättigheterna. Sveriges anslutning till Europarådets konvention angående skydd för de mänskliga rättigheterna och de grundläggande friheterna föranledde en bety- 
delsefull debatt i kriminalistföreningen vid årsmötet 1954. Inledningar om de mänskliga rättigheterna, straffprocessen och frihetsberövandet hölls av Agge och sedermera professorn Hilding Eek (1910-1983) vilka trots kallsinnighet från andra visade på svårigheterna att förena de internationella åtagandena med gällande svensk lagstiftning och rättstillämpning.

Såsom ovan nämnts, tog Hurwitz redan 1943 initiativet till bildandet av Dansk kriminologisk selskab. Erfarenheterna från denna sammanslutnings verksamhet gav Schlyter som ordförande i Svenska kriminalistföreningen idén 1945 att skapa ett motsvarande forum, som fick namnet Kriminalpolitiska sällskapet och blev ett livligt forum för meningsutbyte i friare former inom huvudstadsområdet. Fem år senare tillkom 1950 Kriminalpolitiska sällskapet $i$ Göteborg, som nu ligger i Törnrosasömn och 1962 bildades Kriminalpolitiska sällskapet i Skåne, som har fått en fast anknytning till kriminalistföreningen och nu verkar som en lokalavdelning av denna. Det kan också nämnas, att man i Norge på motsvarande sätt 1956 bildat Kriminalpolitisk forening. Otvivelaktigt har dessa svenska sällskap verksamt bidragit till att föra människor samman till kriminalpolitiska överläggningar $\mathrm{i}$ former, som den till Stockholm i ämbetstraditionen rotade föreningen icke kunnat erbjuda. Likväl måste det sägas, att 1950-talet för Svenska kriminalistföreningen blev en lyckosam period, kanske därför att impulser från den internationella debatten nådde Sverige vid en tidpunkt, då argumenten kring strafflagsreformen blivit uttömda.

\section{Det senaste kvartsseklet}

När den nyvalde ordföranden Beckman vid Svenska kriminalistföreningens årsmöte 1960 öppnade sammanträdet, yttrade han minnesord över de två som sedan föreningens tillkomst varit ledande män inom kriminalpolitiken: Schlyter och Kinberg. Vid det följande mötet 1961 gav Agge en tillbakablick över föreningens 50-åriga historia och dåvarande lagbyråchefen Holmberg en redogörelse för brottsbalksförslaget, som efter lagrådsgranskning nu var moget att inom kort upphöjas till lag. Följande år inledde Göranssons efterträdare som chef för făngvården, generaldirektören Torsten Eriksson (1896-1977) en överläggning om den svenska kriminalvårdens framtid. Nu nådde förhoppningarna om goda behandlingsresultat sin höjdpunkt bland dem som deltog i diskussionen.

Till de under föreningens hela verksamhetstid gång efter annan återkommande ämnena hör psykiskt störda lagöverträdare och deras omhändertagande inom eller utom det straffrättsliga påföljdssystemet. Under påverkan av Kinberg hade Schlyter fått tillräknelighetsläran i det närmaste utrotad ur Brottsbalken. Det psykiatriska undersökningsväsendet hade under lång tid drabbats av kritik från allmänheten och misstro från domstolarna och en ny 
organisation höll på att växa fram. Mot denna bakgrund gav professorn i rättspsykiatri Gösta Rylander (1903-1979) sitt anförande vid årsmötet 1963 rubriken: Bedömer eller dömer de rättspsykiatriskt sakkunniga? Frågan besvarades olika av deltagarna i diskussionen. Ämnet har ännu aktualitet, även om förutsättningarna har ändrats.

För många svenska kriminalister blev FNs tredje världskongress om förebyggande av brott och behandling av brottslingar 1965 i Stockholm decenniets stora händelse och en personlig framgång för Eriksson som organisatör. Den svenska ståndpunkten till kriminalvården markerades starkt av den svenska justitieministern (1959-1969) Herman Kling (1913-1985), när han yttrade: Behandlingen av brottslingen bör icke utformas efter vad han själv kan anses vara värd, den bör vara samhället värdig. Detta ställningstagande gäller förhoppningsvis än idag.

Vid årsmötet 1969 lämnade Göransson ordförandeposten till Holmberg och det förekom efter valet till styrelse en diskussion med Strahls efterträdare på professuren Alvar Nelson (f 1919) och dåvarande riksåklagaren Holger Romander (f 1921), nu rikspolischef som inledare över ämnet: Är Brottsbalken redan omodern? Då hade det bara gått några få år från dess ikraftträdande 1965 . Idag torde ungefär hälften av dess stadganden ha ändrats, och nya, omfattande ändringar är att vänta. Det hade knappast Ekeberg, Kling eller Schlyter väntat sig av utvecklingen. Under 1970-talets förra hälft blossade en debatt om lag och ordning upp och politikerna uttryckte sin oro över utvecklingen och över det tilltagande missbruket av alkohol och narkotika. Detta präglade också den debatt som föreningen anordnade 1973 med en panel inbjudna. Samma år höll kriminologiprofessorn Knut Sveri (f 1925) inledningen till en diskussion i föreningen om våldet i samhället. Sådana ofärdsindikatorer dyker återigen upp på höstmötet 1979, då en panel diskuterar alkohol, psykofarmaka, självmord, sjukdagar, förtidspensionerade och kriminalitet $\mathrm{m}$ m i en osalig blandning.

Redan på höstmötet 1971 inledde docenten Göran Elwin (f 1940) debatten om tidsobestämda frihetsberövanden. Då hade man redan börjat ifrågasätta rimligheten av vad som sades vara »straff för framtida brott«. Analys av resultaten av användningen av ungdomsfängelse visade klart, att påföljdsformen icke infriade förväntningarna, och inom påföljden internering hade andra grupper samlats än dem, för vilka den hade avsetts. Ungdomsfängelse avskaffades 1979 och internering 1981. Eljest fångade utformningen av kriminalvård i frihet större uppmärksamhet. Vid årsmötet 1972 diskuterades service och kontroll inom frivården med skyddskonsulenten Barbro Schillander-Lundgren (f 1928) som inledare. På höstmötet 1975 inledde Tor Sverne (f 1925), numera justitieombudsman och Birgit Hindersson (f 1926), numera skyddskonsulent en överläggning om fångvårdens ansvar. 
Den inom Brottsförebyggande rådet av arbetsgruppen rörande kriminalpolitik framlagda rapporten Nytt straffsystem presenterades för föreningen av numera hovrättslagmannen Erland Aspelin (f 1931) och numera departementsrådet Sten Heckscher (f 1942). Debatten i press och facktidskrifter var mera ingående än den, som fördes i föreningen. Ändå innebar rapporten det tydligaste brottet mot den ideologiska tradition, som länge vårdats där.

Vid årsmötet 1980 lämnade Holmberg över ordförandeskapet till Sjöberg, som nu leder föreningen. Vid det tillfället förekom en överläggning om utlänningar och brottslighet med en panel, där olika intressen företräddes. Den debatten har senare förts vidare under lång tid bl a i NTfK. Sedan 1980 har invandringen till Sverige i väsentlig omfattning ändrat karaktär icke minst genom tillströmningen av flyktingar från fjärran länder i krig, inrikes oro eller nöd. Många kände i luften att det kriminalpolitiska klimatet förändrats. Mycket kom dock icke fram vid debatten 1981 mellan den förre justitieministern (1969-1976) Lennart Geijer (f 1909) och hans moderate efterträdare Håkan Winberg (f 1931).

Anstaltsvården beredde sedan länge myndigheterna svårigheter och mötte kritik från många håll såsom alltför dyrbar och ineffektiv. Detta påverkade i det långa loppet även kriminalvårdsverkets personal. En lösning, som låg nära till hands, var en sänkning av straffnivån och ökad användning av böter. Det var därför icke överraskande, att överdirektören Bo Svensson (f 1940) Brottsförebyggande Rådet (BRÅ) på höstmötet 1982 i föreningen inledde en debatt om böter i stället för fängelse. Nu väntar många att Fängelsestraffkommittén i sitt under våren 1986 kommande betänkande skall föreslå en allmän sänkning av straffnivån.

Det senaste större lagstiftningsprojekt, som presenterats för föreningen var Förmögenhetsbrottsutredningens betänkande, som strax på hösten 1983 presenterades av ordföranden f hovrättspresidenten Karl-Erik Skarvall (f 1915), sekreteraren hovrättsrådet Barbro Hegrelius Jonson (f 1943) och experten Nils Jareborg (f 1938), numera Nelsons efterträdare i Uppsala. Det i förtid avbrutna utredningsarbetet innebar så genomgripande förändringar, att det mötte mindre framgång, än det förtjänar.

Större uppmärksamhet mötte presentationen 1984 av en liten promemoria med anledning av kritiken om förmåner för »lyxfångar« med inledning av statssekreteraren Lennart Myhlback (f 1945), numera chef för statens räddningsverk, överdirektören i kriminalvårdsstyrelsen Marianne Håkansson (f 1941) och Elwin. Desto större var problemområdet, när fil dr Jerzy Sarnecki (f 1947) BRÅ 1985 visade gängstrukturer i föreningens diskussion om ungdomsbrottslighet och samhällsförändring. 


\section{Aterblick och framtidsutsikter}

Svenska kriminalistföreningens utveckling hänger nära samman med formerna för den kriminalpolitiska debatten. Som forum för meningsutbyte har den minskat $\mathrm{i}$ betydelse och haft svårigheter att vinna nya medlemmar, som vill offra tid och intresse på mötena. Denna tendens var märkbar redan under 1960-talet och har icke kunnat brytas trots aktningsvärda försök till förnyelse av mötesformerna bl a genom paneldebatter. Det gamla gardet från storhetstiden möter ännu upp och yttrar sig, ibland med ålderns rätt. De yngre tar mera sällan till orda men lyssnar gärna, när en arbetskamrat är bland inledarna.

Styrelsens starka förankring i departement och centrala ämbetsverk kan ha lett till en viss försagdhet bland yngre i karriären, åtminstone när de har en från inledaren avvikande uppfattning. Inledningarna, särskilt $\mathrm{i}$ fråga om lagförslagen, blir lätt en sammanfattning av en föredragning inför beslutsfattare. Icke desto mindre förekommer överraskningar, $\mathrm{t}$ ex när lagmannen Bertil Wennergren (f 1925) 1982 lade fram en del av sin utredning om straffprocessuella tvångsmedel samma dag som regeringen beslutat, att den tills vidare skulle läggas å sido. Något liknande låg i luften, när försäkringsrättsrådet Lars Grönwall (f 1938) 1984 gav en sammanfattning av socialberedningens betänkande om Psykiatrin, tvånget och rättssäkerheten.

Visst väntade man på starka reaktioner på BR $\AA$-rapporten Nytt straffsystem, men i föreningen var det ett stillsamt meningsutbyte mellan Geijer, som ogillande dess ideologi, och Winberg. Annat var det i tidskriften Tiden 1981 då Sten Heckscher besvarade ett våldsamt angrepp från Ingemar Hedenius (1908-1982). Den äldre generationen har svårt att förlika sig med tanken på en straffrättskipning, som sker med utgångspunkt från brottet och icke från brottslingen. Återigen byter man nu blickpunkt och låter brottsoffret komma i förgrunden med anspråk på styrning av myndigheternas ingripande. Här väntar ett nytt överläggningsämne för nästa årsmöte.

Mindre sannolikt är det, att föreningen vågar sig in i debatten om rättssäkerheten vid samhällsingripanden. Vad regeringen med utgångspunkt i den $\mathrm{s} \mathrm{k}$ eko-kommissionens förslag anförde i propositionen i samma ämne väckte blandade känslor, t o m i riksdagen. Då gällde det närmast de straffrättsliga ingripandena. $\mathrm{Nu}$ står de socialrättsliga ingripandena mot ungdom och missbrukare i förgrunden. Dessutom har förutsättningarna för användningen av straffprocessuella tvångsmedel mot person (anhållande och häktning) och bruket av sådana medel nu kommit under förnyad debatt.

Redan under Geijers tid markerade regeringen, att straffrättskipningen vid de allmänna domstolarna skulle inriktas på grövre och komplicerade brottmål. Processekonomiska hänsyn talade för ökad användning av de summariska strafförfarandena (föreläggande av ordningsbot och strafföreläggande) och 
åtalsunderlåtelse skulle komma till användning i ökad omfattning, ibland av hänsyn till lagöverträdaren, vanligen därför att brottet icke drabbade något väsentligt enskilt eller allmänt intresse. Redan 1975 diskuterades på årsmötet frågan om åklagare som domare med numera regeringsrådet Bertil Werner ( $\mathrm{f}$ 1933) som inledare. Måhända är det nu åter anledning att taga upp ämnet.

Ännu större aktualitet har överföringen av ingripanden mot lagstridiga handlingar från straffrätten till förvaltningsrätten och från domstolar till administrativa myndigheter genom en utbyggnad av systemet med $\mathrm{s} k$ sanktionsavgifter. De bestämmes av lokala eller centrala myndigheter inom mer eller mindre vida ramar med obestämda möjligheter till nedsättning eller bortfall av avgiften. Sådana avgifter får uttagas även av juridiska personer och förutsätter icke straffrättslig skuld. Därtill kommer, att bevisbördan flyttas över på överträdaren, som har att förebringa ursäkter till sitt fredande. Sådana ingrepp i reaktionssystemet är värt överväganden från många utgångspunkter, däribland även frågan om insyn $\mathrm{i}$ verksamheten och offentlighet åt meddelade beslut.

De antydningar som här har givits om uppgifter för kriminalistföreningen kan sammanfattas i gamla slagord, som ständigt behöver nya överväganden: allmänprevention ./. individualprevention och rättssäkerhet ./. effektivitet samt offentlighet ./. sekretess. Ämnena finnas där. Uppgiften för föreningen är att formulera tydliga debattämnen och att finna inledare, vilka icke är bundna av offentliga direktiv utan villiga att lägga fram en självständig, genomtänkt ståndpunkt. Särskilt betydelsefullt är det att få frågorna belysta genom erfarenheter i det praktiska rättslivet och att göra människorna synliga, när de sprattlar som fiskar i lagstiftningens nät eller söker sig till nya verksamhetsområden utom räckhåll för myndigheterna.

Svenska kriminalistföreningen har sin uppgift i brottets värld. De internationella frågorna, där de nordiska föreningarna trädde in med vissheten, att de kunde bidraga till nya och humana lösningar, făr nu sin belysning genom ländernas officiella delegater, vilkas personliga ståndpunkt har liten tyngd. Desto viktigare blir det, att de genom sina kontakter med utvecklingen i hemlandet făr möjlighet att $\mathrm{i}$ förväg påverka innehållet i det ställningstagande de skall företräda. Här kan meningsutbyte inom de nordiska föreningarna och dem emellan verka.

Till jubiléet en blomsterbukett med flera slags blommor i många färger!

Adresse: Professor em., jur. dr Alvar Nelson

Juridicum

Box 512

S-751 20 Uppsala 